International Journal of Business Management and Economic Review

Vol. 4, No. 04; 2021

ISSN: 2581-4664

\title{
EVALUATION OF THE MANAGEMENT OF TRAINING OPERATIONS IN PUBLIC INSTITUTIONS ACCORDING TO THE GUIDING SPECIFICATION (ISO10015: 2019) / A CASE STUDY IN THE IRAQI MINISTRY OF INTERIOR
}

\author{
Areej s. Khaleel ${ }^{1} \&$ Hussien S. Shaker ${ }^{2}$ \\ ${ }^{1}$ Middle Technical University, Baghdad, Iraq. \\ ${ }^{2}$ Ministry of Interior , Baghdad, Iraq. \\ http://doi.org/10.35409/IJBMER.2021.3301
}

\begin{abstract}
The study aims to measure and analyze the actual reality of training operations management and its compatibility with the competency management system and personnel development according to the guiding requirements of the standard (ISO 10015: 2019) at the Ministry of Interior. Field visits and personal observations of researchers were conducted to reach the scientific and practical facts. The adopted the case study approach by using the checklist as a tool for collecting data and information. (8) formations were selected out of (59) formations affiliated with the Iraqi Ministry of Interior. The results showed that the Ministry of Interior suffers from a weakness in the management of the implementation of training programs, which negatively affected the quality of the training program objectives. In addition to the absence of local or international standards adopted by the Ministry of Interior in the training management system, despite the presence of organizational units concerned with the application of quality in the training management. It is the first study at the level of the Iraqi environment that deals with the guiding requirements of the standard (ISO 10015: 2019). The dimensions covered by the study were characterized by disclosing the reality of the Department of Training Operations in the Ministry of Interior. Accordingly, the study presented a different model from what the previous studies dealt with in evaluating the reality of training operations management.
\end{abstract}

Keyword: Iraqi Ministry of Interior, Training, Training Operations Management, ISO 10015: 2019.

\section{INTRODUCTION}

Organizations are experiencing great change due to new technologies, rapid development of knowledge, globalization of business and development in e-commerce. For organizations to remain competitive in this environment. They must take steps to attract, retain and motivate their workforce, employee retention and growth, the economy, a multi-generational workforce, the use of new technology, and the expansion of learning beyond the classroom-all of these are just Some problems that affect organizations in all areas. This influence extends to reach the impact on training practices. Many organizations realize that learning goes beyond university enrollment. They use technology to facilitate employee learning in different locations and knowledge sharing through formal courses. As well as through cooperation. Therefore, training is not a secondary option, as it is necessary for organizations to participate in global and 
International Journal of Business Management and Economic Review

Vol. 4, No. 04; 2021

ISSN: 2581-4664

electronic markets by providing high quality products and services. Where training prepares employees to use new technologies and work in new work systems such as virtual teams, communication and cooperation with peers or customers who may be from different cultural backgrounds, a study (Clark, 1992) indicated that training has two special characteristics that make its effective management different from the management of other jobs, These two characteristics are: (1) an internal service that is not usually seen as central to the core business, and . (2) An attempt to influence human performance. This study lays out a method for effectively managing training in developing a marketing plan and monitoring developments in training. As for a study conducted by (Chang, et al., 2004), it reviews studies that deal with the factors affecting the management of training in Chinese institutions. It indicated that there are major factors affecting Chinese training institutions represented in the lack of funds allocated for training, low standards of management, lack of professionalism, and weakness in rules and regulations. Researchers emphasize that improving training management and productivity is the basic way for Chinese companies to achieve develop in the future. A study (Rahmi, et al., 2021) indicated that training in the use of technology is one of the suggestions that must be improved in dealing with learning in the twenty-first century. Infrastructure needs to be taken care of so that the programs that have been prepared to improve the trainee's performance can be implemented effectively and efficiently in the South District Education Office (Aceh). The results of the study (Utomo \& Ruslan, 2021) found that organizations do not yet have a management of employee training and development, and that the human resource development process is not able to formulate employee development patterns. Organizations need to conduct a comprehensive assessment of the occurrence of a vacancy in the management system for employee training and development. The results also showed the neglect of management when there is a vacancy in the personnel development job by the human resources development department in the organizations.

The main objective of the study is to assess the actual reality of the management of training operations in the Ministry of Interior through the dimensions identified by the study based on the requirements of the guiding specification (ISO 10015: 2019) and the requirements of the international standard (ISO 9001: 2015). The study consists of a group of sections that start with theoretical framing and then review the methodology and procedures for the study, and then clarify the results, discussions and the abstract.

\section{TRAINING}

Organizational success mainly depends on the role and style of leadership which is a critical factor in dealing with the problems encountered in terms of planning, management, human resources and leadership. Therefore, developing skills in leadership quality for senior management in an organization is a major and essential aspect to improve its performance (Degraft-Otoo, 2012: 9). Therefore, training is one of the most important activities of human resource management, which shows that a well- planned and organized procedure helps the trainee to acquire knowledge, abilities and skills to maintain his activities in an effective and efficient manner. Training is a systematic method that benefits organizations in developing and improving the quality of existing employees. It is also an organized method of collecting and expanding knowledge that works on the development of the individual, the group, and the organization (Jeni \& Al-Amin, 2021: 3). Therefore, training is a continuous process, not a 


\section{International Journal of Business Management and Economic Review}

Vol. 4, No. 04; 2021

ISSN: 2581-4664

temporary one, in light of the rapid developments in technology and knowledge. Training plays a very big role in preparing employees to be more creative in achieving the goals of the organization effectively and efficiently (Prasetyo \& Arafat, 2021: 576). The improvement in the performance of any organization occurs as a result of gaining a competitive advantage mainly by enhancing the skills and efficiency of employees and the knowledge they obtain from training. Therefore, training is necessary for all organizations. Keeping abreast of technologies, new technology, staff competencies, innovation and creativity are the results of the training and development process. Organizations should identify the need for training and development in addition to selecting appropriate techniques and developing a strategy for the implementation plan towards the last important step, which is the evaluation of results (Misra \& Mohanty, 2021: 6).Training is defined as the part of education associated with the process of learning to acquire and improve skills outside the current education system in a relatively short time using methods that give priority to practice rather than theory (Marnisah, et al., 2021: 20). In the context of public security training institutions, it is defined as the practical, scientific, theoretical and applied efforts undertaken by the training cadres of the security services cooperating with them to determine the actual needs for training, prepare annual plans, design, implement, evaluate and develop their programs with the aim of providing their trainees, officers and their workers with knowledge, improving competencies and participating in The stages of making decisions and benefiting from work teams and enabling institutions to address their problems, face their challenges, and achieve the goals for which they were established effectively and efficiently. So training is a systematic way of determining what needs to be done to bring performance in a particular job to the expected level (Seyoum, 2015: 23). and addressing human problems for peaceful industrial relations (Degraft-Otoo, 2012: 21). Training is also required to identify and analyze the needs of employees who lack the knowledge, skill, and abilities to do the job (Mwesigwa, 2010: 25). The main purpose of the technology and its primary purpose is to improve knowledge and skills and change attitudes or behavior, as it is one of the most important potential motivators that can lead to many potential benefits for both individuals and the organization, and technology change requires that employees possess the knowledge, skills and capabilities necessary to deal with operations New Production Techniques (Engetou, 2017: 11).

\section{GUIDANCE STANDARD (ISO 10015: 2019)}

Since the publication of the ISO on 15 March (1987) the standard (ISO 9000) has become a global trend and a common language for quality. The standard (7. Support) in the specification (ISO 9001: 2015) covers some requirements that clarify the procedures for dealing with human resources and individuals and the way to deal with them, develop them and raise their efficiency, which requires organizations to train new employees and the work of employees to influence the quality of the product or service. Training of employees helps to increase the performance of the organization so the organization should take into account its vision, strategies, experts and management tools. Everyone expects to have a quality system that helps organizations improve their training and learning system. Therefore, the (ISO) worked on issuing a specification related to training processes in organizations and how to deal with them, so in (1999) the standard (ISO 10015) was issued, which was the hope for organizations to provide a new standard for them that clarifies guidelines for training on the philosophy of the wheel (PDCA) to ensure procedures Operating Organizations in Training (Lin, et al., 2010: 4120). In (2015), the ISO organization 


\section{International Journal of Business Management and Economic Review}

Vol. 4, No. 04; 2021

ISSN: 2581-4664

sought to develop the first version of the standard (ISO 10015) and through the numbered Technical Support Technologies Committee (ISO/TC 176/SC 3 Supporting technologies) to work on a newer version of the standard (ISO 10015) in line with the latest technological developments These efforts culminated in the issuance of the standard (ISO 10015) in (2019) (www.iso.org)

\section{DIMENSIONS OF TRAINING OPERATIONS MANAGEMENT}

- Leadership: The training institution must have a qualified and effective administration that works on managing the institution, achieving its goals, and creating a positive work environment characterized by a team spirit within a framework of integrity, transparency and justice. Leadership encourages initiatives and development proposals, participates in decision- making, appreciates constructive contributions, and motivates outstanding performance

- Quality Assurance System: The training institution must have a quality assurance system in all its activities to enable the organizational structure of the training institution to carry out its tasks and activities effectively.

- Resources: The training institution must have the financial, human and technical resources, facilities and equipment that serve its training activities and operations and help meet all its needs.

- Training Operations: The institution must have a system for designing and reviewing the training programs it offers. It defines the contents and skills expected in each program, in addition to providing training manuals, training aids, new techniques, necessary analogies, and sufficient sources of information. The training institution must have an effective mechanism to follow up and support the trainees.

- Trainees: The conditions and procedures for joining training programs must be clear. The institution must also provide the necessary information and services to its trainees.

- Trainers: The institution must have a sufficient number of trainers. And that the training institution has a program to evaluate the performance of trainers.

Safety and Risk Management: The organization must provide a safe and risk-free training work environment by achieving safety and security requirements to protect facilities, property and individuals. Assessing potential risks and preparing a plan to manage them and reduce their effects.

\section{METHODOLOGY}

The actual reality of the management of training operations in the Ministry of Interior will be evaluated through conducting audits and using direct observation and field experience in a number of study formations. A checklist for the study was prepared that addresses the specific dimensions of the study. A sample of (8) formations affiliated to the Iraqi Ministry of Interior was selected out of (59) formations. Those formations were as follows (General Traffic Directorate, General Rescue Directorate, Civil Status, Passports and Residence Directorate, Civil Defense Directorate, Baghdad Police Command, Criminal Evidence Directorate, Infrastructure Directorate, Federal Police Command). This sample size represents approximately (20\%) of the total number of the ministry's formations. The reason for choosing these formations as a sample 


\section{International Journal of Business Management and Economic Review}

Vol. 4, No. 04; 2021

ISSN: 2581-4664

for training operations at the ministry level is due to a number of reasons, which we explain as follows:

- The organizational structure of the customary Ministry of Interior is divided into (4) agencies linked to His Excellency the Minister of Interior. A sample was selected from each agency (4 formations from the Ministry's Agency for Police Affairs - 2 formations from the Ministry's Agency for Administrative and Financial Affairs - 2 formations from the Ministry's Agency for Federal Security Affairs). As for the Federal Intelligence and Investigation Agency, the study did not address any of its formations within the selected formations, because of its complete secrecy and its dealings with sources of security information that affect national security.

- The selected formations are considered one of the most important priorities of the ministry's work and included in the general strategic plan of the Ministry of Interior for the years (20192023) in preparing the requirements of the security file in Baghdad and the governorates in terms of building the capabilities of the federal police forces and reorganizing them, building the capabilities of the local police and developing the capabilities of its employees Security services provided by the Ministry's departments (Traffic Directorate - Directorate of Civil Status, Passports and Residence - Directorate of Civil Defense - Directorate of Criminal Evidence).

- The above (8) formations were chosen for two reasons: (the formations that were selected represent the largest percentage of the human resources working in the Ministry of Interior, as they represent more than (250) thousand members out of the total number of the Ministry of the Interior's employees, which is (582) thousand members The selected formations contain schools and training centers within their organizational structure.

Therefore, the researcher will be accredited to fill the checklists with the required information through personal interviews and actual observations to ensure the accuracy of the information, and through the use of the seven-point Likert scale.

\section{RESULT AND DISCUSSION}

From Table (1) it is clear that the leadership standard and by relying on the actual application and documentation of the management of training operations in the Ministry of Interior. The Directorate of Nationality achieved the highest weighted arithmetic mean of (3) with a matching percentage $(50 \%)$. Which indicates the existence of a gap or non-conformities of its amount (50\%). As for the Directorate of General Rescue, it achieved the lowest weighted arithmetic mean of (2.25), with a matching rate of (38\%). This indicates the presence of a gap of (62\%). As for the other six formations, they achieved arithmetic means, matching percentages, and gaps that ranged between the values obtained by the Directorate of General Nationality and the values obtained by the Directorate of General Rescue. This shows that the Ministry of Interior possesses competent security leaders with extensive experience in security and military work and supports research and progress in all fields. Policies and procedures are available to support public values and military discipline for all its members and work in a team spirit. However, these leaders should pay attention to the formation message, and it should be announced, understood and available to all employees, as it is the lofty goal of the formation. In addition to the need to ratify the organizational structure of all the formations of the ministry and create a job description for the workers in the formations that defines the tasks and powers of each job. There should be an approved system to measure the job satisfaction of employees and evaluate their performance 


\section{International Journal of Business Management and Economic Review}

Vol. 4, No. 04; 2021

ISSN: 2581-4664

according to approved institutional standards and to benefit from them in the process of continuous improvement, establishing clear and announced regulations and procedures that define the rights of employees.

As for the quality assurance system standard, from Table (1) it is clear that the highest arithmetic average achieved by the Traffic Directorate was (2.66) and a matching percentage (44\%), which indicates the presence of a gap or non-conformity cases of (66\%). As for the lowest arithmetic mean, it was achieved by the Baghdad Police Command by (1.66). And with a matching percentage (28\%), which indicates the existence of a gap of $(72 \%)$, as for the other six formations, they achieved weighted arithmetic means and a matching percentage and gaps that ranged between the values obtained by the Traffic Directorate and the Baghdad Command Directorate. This shows that the Ministry of Interior has quality management divisions in all of the ministry's formations that are linked to the higher management of the formation. The Ministry of Interior has a unified database that provides the necessary statistical data and information at all levels, so the ministry's formations must be qualified to work in accordance with the requirements of the quality management system in accordance with the international standard (ISO 9001: 2015). Supporting the quality people with professional cadres with experience in the field of quality management, adopting a system to follow up work procedures. Using a unified model to maintain and improve performance indicators approved by the Ministry, as they do not specify the level of performance in an elaborate manner, and to benefit from feedback to evaluate work and services provided to beneficiaries in the process of evaluation and improvement.

As for the resource standard, and by relying on the actual application and documentation for the management of training operations in the Ministry of Interior. The Federal Police Command achieved the highest weighted arithmetic mean of (3.13) and a matching percentage (52\%). This indicates the existence of a gap or non-conformity of the amount of (48\%), as for the Traffic Directorate, it achieved the lowest weighted arithmetic mean of (2.17) and with a matching rate of (36\%), which indicates the existence of a gap of (64\%). As for the other six formations, they achieved weighted arithmetic means, matching percentage, and gaps that ranged between the values obtained by the Federal Police Command Directorate and the Al-Marw Directorate. This shows that the Ministry of Interior has an information system that provides the information it needs as quickly as possible, which is a source of strength in carrying out its tasks, in addition to the necessary measures to protect its vital facilities. Therefore, a plan must be prepared for the professional development of all employees in the ministry, providing the necessary and appropriate infrastructure and material and technical equipment, and providing them with preventive and corrective maintenance necessary to perform the work in the required manner, and providing occupational health and safety requirements for all institutions and formations specialized in training specifically and paying attention to the requirements of catering and adequate housing for workers.

With regard to the standard of training operations, the Federal Police Command achieved the highest weighted arithmetic mean of (4.17) with a matching rate of (69\%), which indicates the existence of a gap or mismatches of (31\%). As for the Infrastructure Directorate, it achieved the 


\section{International Journal of Business Management and Economic Review}

Vol. 4, No. 04; 2021

ISSN: 2581-4664

lowest weighted arithmetic mean of (2.25) and a matching percentage (37\%), which indicates the existence of a gap of (67\%). As for the other six formations, they achieved weighted arithmetic means, matching ratio, and gaps that ranged between the values obtained by the Federal Police Command Directorate and the Infrastructure Directorate. The training expected to be offered, which is related to its identity, mission and objectives that are commensurate with strengthening military discipline and emphasizing the identity and military culture. It shall be announced and include the content of the training programs, their requirements, the training periods associated with them, the duration of each program, the number of hours, requirements for completing the program and effective training strategies to ensure that the trainees acquire the necessary knowledge and skills Maintaining secure electronic records of the trainees' grades and data, so the training impact of the trainees must be evaluated during and after the completion of the training program according to approved models in this field, establishing a library to provide the required references that serve the various training programs, specifying the available times for using the library, and coordinating to benefit From the relevant national libraries and information bases, allocating the material resources necessary to provide assistance to the training processes, techniques and paraphrases needed to implement the training programs, while providing preparation programs for their use, taking appropriate measures for the programs adopted by the institution through local and global partnerships, including the compatibility of their content with the values and culture of the community and the military identity and security.

As for the trainees' criterion, the Directorate of Criminal Evidence has achieved the highest weighted arithmetic mean of (2.39) out of a matching rate of $(39 \%)$, which indicates the existence of a gap or mismatch of $(61 \%)$. As for the Traffic Directorate, it achieved the lowest weighted arithmetic mean of (1.25) and a matching percentage (21\%), which indicates the existence of a gap of (79\%). As for the other six formations, they achieved weighted arithmetic means, matching percentage, and gaps that ranged between the values obtained by the Directorate of Criminal Evidence and the Directorate of Traffic. This shows that the trainees' acceptance processes and levels are consistent with the objectives of the security establishment and the needs of the sectors benefiting from training. As the institution seeks to involve the trainees according to programs that are compatible with the nature of the work entrusted to them at all levels, therefore, special committees must be formed to set up a mechanism to verify the availability of admission requirements for the candidates, and to organize an organized regulation of behavior that shows the rights and duties of the trainee, and disciplinary and grievance procedures that are announced and accessible to the trainee, and apply Programs to prepare new trainees that include introducing them to the training content, regulations, services, rights and duties assigned to them, surveying trainees' opinions about the services provided to them according to standard models approved in this field to benefit from their results in the development and improvement process, encouraging trainees to participate in various training activities outside training hours, and providing Medical, counseling, social and psychological services and approprite support for trainees.

As for the criterion of trainers, the Federal Police Command achieved the highest weighted arithmetic mean of (2.33) and a matching rate of (39\%), which indicates the existence of a gap or mismatch of (61\%). As for the Directorate of General Rescue, it achieved the lowest weighted 


\section{International Journal of Business Management and Economic Review}

Vol. 4, No. 04; 2021

ISSN: 2581-4664

arithmetic mean of (0.5) with a matching rate of $(8 \%)$. This indicates the existence of a gap of $(92 \%)$, as for the other six formations, they achieved weighted arithmetic means, matching percentage, and gaps that ranged between the values obtained by the Federal Police Command and the Directorate of General Development. This indicates that the Iraqi Ministry of Interior suffers from a lack of trainers who enjoy With high efficiency in all police fields, therefore, a sufficient number of trainers must be provided in proportion to the capacity of each institution. Develop an appropriate plan to develop the current trainers, prepare them to work on modern training and teaching methods and methods, form permanent committees to verify the credibility of the qualifications and experiences of the concerned training staff members and those transferred to them, and develop a mechanism to motivate trainers to achieve the highest degree of efficiency in their work.

As for the safety standard of risk management, the Directorate of Civil Defense, the Directorate of Criminal Evidence and the Federal Police Command achieved the highest weighted arithmetic mean of (4.22) and with a matching percentage (70\%), which indicates the existence of a gap or non- conformities of $(30 \%)$. As for the Traffic Directorate, it achieved the lowest weighted arithmetic mean of (3.44) with a matching rate of (57\%), which indicates the existence of a gap of (43\%). As for the other six formations, they achieved weighted arithmetic means, matching percentage, and gaps that ranged between the values obtained by the Civil Defense Directorate, the Criminal Evidence Directorate, the Federal Police Command and the Traffic Directorate This shows that the Ministry of Interior institutions are working to implement the local defense plan with fixed periods that ensure the involvement of all employees, which ensures the preservation of safety from all types of risks and works to update and maintain safety systems periodically in accordance with the approved requirements, so special formations for risk management must be developed, the task of which is to develop a risk management plan that ensures the appropriate response to each event, the application of appropriate mechanisms to dispose of waste and hazardous materials in cooperation With the competent authorities, assessment of potential risks in all aspects periodically by all institutions.

Table1. The degree of conformity of the formations of the Iraqi Ministry of Interior.

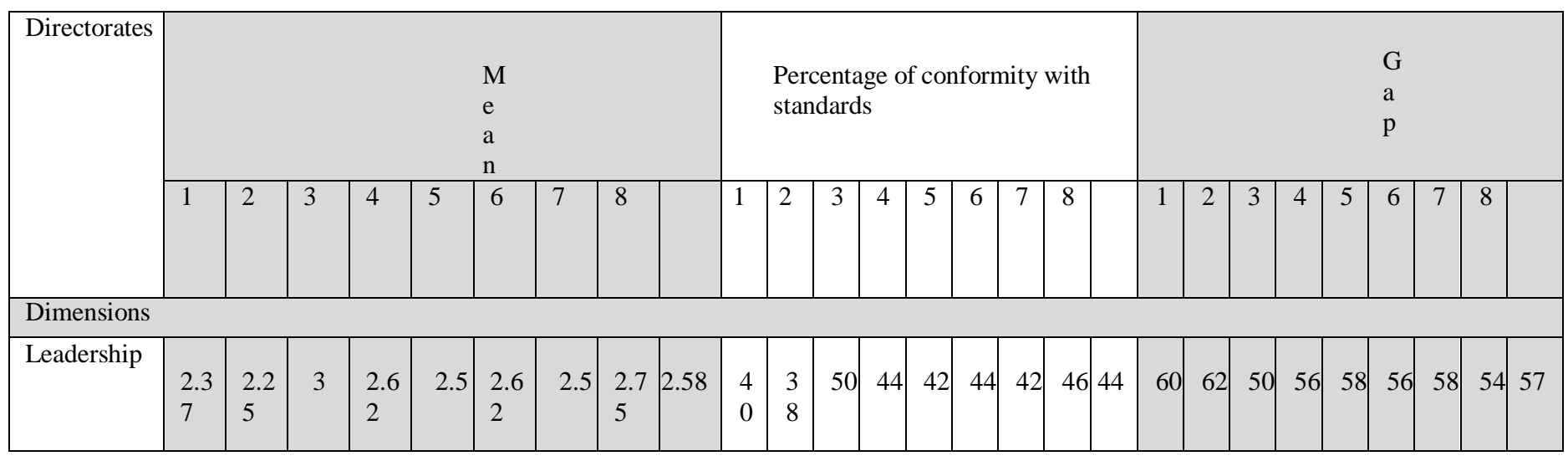




\section{International Journal of Business Management and Economic Review}

Vol. 4, No. 04; 2021

ISSN: 2581-4664

\begin{tabular}{|c|c|c|c|c|c|c|c|c|c|c|c|c|c|c|c|c|c|c|c|c|c|c|c|c|c|c|c|}
\hline $\begin{array}{l}\text { Qualit } \\
-y \\
\text { Assur } \\
\text { ance } \\
\text { Syste } \\
\text { m }\end{array}$ & $\begin{array}{l}2.6 \\
6\end{array}$ & 2 & $\begin{array}{l}2.3 \\
3\end{array}$ & 2 & $\begin{array}{l}1.6 \\
6\end{array}$ & $\begin{array}{l}2.3 \\
3\end{array}$ & $\begin{array}{l}2.1 \\
7\end{array}$ & $\begin{array}{l}1.8 \\
3\end{array}$ & 2.12 & $\begin{array}{l}4 \\
4\end{array}$ & $\begin{array}{l}3 \\
3\end{array}$ & 39 & 33 & 28 & 39 & 36 & 31 & 35 & 56 & 67 & 61 & 67 & 72 & 61 & 64 & 69 & 65 \\
\hline Resources & 2.1 & 2.2 & 3.0 & 2.2 & 2.5 & 2.5 & 2.7 & 3.1 & 2.59 & 3 & 3 & 51 & 37 & 43 & 42 & 46 & 52 & 43 & 64 & 62 & 49 & 63 & 57 & 58 & 54 & 48 & 57 \\
\hline Training & $\begin{array}{l}3.1 \\
7\end{array}$ & $\begin{array}{l}3.1 \\
7\end{array}$ & $\begin{array}{l}4.0 \\
8\end{array}$ & $\begin{array}{l}3.2 \\
5\end{array}$ & $\begin{array}{l}3.8 \\
3\end{array}$ & $\begin{array}{l}2.9 \\
2\end{array}$ & $\begin{array}{l}2.2 \\
5\end{array}$ & $\begin{array}{l}4.1 \\
7\end{array}$ & 3.36 & $\begin{array}{l}5 \\
3\end{array}$ & $\begin{array}{l}5 \\
3\end{array}$ & 68 & 54 & 47 & 49 & 37 & 69 & 54 & 47 & 47 & 32 & 46 & 53 & 51 & 63 & 31 & 46 \\
\hline Trainees & $\begin{array}{l}1.2 \\
5\end{array}$ & $\begin{array}{l}1.7 \\
5\end{array}$ & $\begin{array}{l}1.8 \\
7\end{array}$ & $\begin{array}{l}1.7 \\
5\end{array}$ & $\begin{array}{l}1.6 \\
2\end{array}$ & $\begin{array}{l}2.3 \\
9\end{array}$ & $\begin{array}{l}1.7 \\
5\end{array}$ & $\begin{array}{l}2.1 \\
2\end{array}$ & 1.81 & $\begin{array}{l}2 \\
1\end{array}$ & $\begin{array}{l}2 \\
9\end{array}$ & 31 & 29 & 27 & 39 & 29 & 35 & 30 & 79 & 71 & 69 & 71 & 73 & 61 & 71 & 65 & 70 \\
\hline Trainers & $\begin{array}{l}0.8 \\
3\end{array}$ & 0.5 & $\begin{array}{l}1.6 \\
7\end{array}$ & 1 & 1 & 1.5 & 1 & $\begin{array}{l}2.3 \\
3\end{array}$ & 1.23 & $\begin{array}{l}1 \\
4\end{array}$ & 8 & 27 & 17 & 17 & 25 & 17 & 39 & 21 & 86 & 92 & 72 & 83 & 83 & 75 & 83 & 61 & 79 \\
\hline $\begin{array}{l}\text { safety and } \\
\text { risk } \\
\text { manageme } \\
\text { nt }\end{array}$ & $\begin{array}{l}3.4 \\
4\end{array}$ & $\begin{array}{l}3.5 \\
5\end{array}$ & $\begin{array}{l}3.8 \\
9\end{array}$ & $\begin{array}{l}4.2 \\
2\end{array}$ & $\begin{array}{l}3.5 \\
5\end{array}$ & $\begin{array}{l}4.2 \\
2\end{array}$ & $\begin{array}{l}3.8 \\
8\end{array}$ & $\begin{array}{l}4.2 \\
2\end{array}$ & 3.87 & $\begin{array}{l}5 \\
7\end{array}$ & $\begin{array}{l}5 \\
9\end{array}$ & 65 & 70 & 59 & 70 & 64 & 70 & 64 & 43 & 41 & 35 & 30 & 41 & 30 & 36 & 30 & 35 \\
\hline $\begin{array}{l}\text { Applica } \\
\text { tion } \\
\text { level }\end{array}$ & $\begin{array}{l}2.2 \\
7\end{array}$ & $\begin{array}{l}2.2 \\
1\end{array}$ & $\begin{array}{l}2.8 \\
5\end{array}$ & $\begin{array}{l}2.4 \\
4\end{array}$ & $\begin{array}{l}2.3 \\
9\end{array}$ & $\begin{array}{l}2.6 \\
4\end{array}$ & $\begin{array}{l}2.3 \\
3\end{array}$ & $\begin{array}{l}2.9 \\
4\end{array}$ & 2.51 & $\begin{array}{l}3 \\
8\end{array}$ & $\begin{array}{l}3 \\
7\end{array}$ & 47 & 41 & 38 & 44 & 39 & 49 & 42 & 62 & 63 & 53 & 59 & 62 & 56 & 61 & 51 & 58 \\
\hline $\begin{array}{l}\text { Application } \\
\text { level at }\end{array}$ & & & & & & $\begin{array}{l}2 \\
. \\
5 \\
1\end{array}$ & & & & & & & & & $\begin{array}{l}4 \\
2\end{array}$ & & & & & & & & & $\begin{array}{l}5 \\
8\end{array}$ & & & \\
\hline
\end{tabular}

Through Table (1) it is clear that the Ministry of Interior achieved a weighted arithmetic mean of (2.51), which indicates that the level of application in the Ministry of Interior reached (42). This resulted in a gap of (58\%), which can be considered a high-level gap on the basis of which attention should be paid to the management of training operations in the Ministry of Interior with all its formations and senior leaders represented by His Excellency the Minister of Interior. This is what was stipulated in Article (5)/Third of the Ministry of Interior Law No. (20) of 2016.

The gaps were close between the formations, and all the formations suffer from a clear weakness in the dimensions of the trainers and trainees and the quality assurance system, and this is due to a set of justifications. As one of the most important reasons that led to the emergence of convergent gaps in the quality assurance system in all formations is due to the centralization system in place in the ministry, as all decisions issued for all formations are issued by the senior leadership. When talking about the quality assurance system, the first responsible for this aspect is the Department of Total Quality Management and Institutional Development. As all the quality divisions in the formations, which number (40) divisions, are administratively linked to the senior leadership of the formation affiliated with it, but at the same time they are technically 


\section{International Journal of Business Management and Economic Review}

Vol. 4, No. 04; 2021

ISSN: 2581-4664

linked to the Total Quality Management and Institutional Development Department. Therefore, the root cause of this problem is the lack of strategic, tactical or operational plans issued by the department above and circulated to all the people to work in their light.

Also, the absence of the necessary mechanisms to verify the availability of admission requirements for candidates for training at the ministry level, and this is considered one of the responsibilities of senior leaders in the decision center in the ministry. Specific criteria should be set for accepting candidates in training courses, as we find that in some formations, elderly individuals, people with disabilities and people whose practical and scientific backgrounds do not match the vocabulary of the course and the training program are nominated. This results in wasting efforts, time and costs allocated to the course because it did not achieve the desired benefit.

The gaps were close in the dimension of trainers in all formations for a set of reasons that can be diagnosed in the planning processes for this dimension, as this is due to the lack of specific and correct criteria for distributing trainers to the formations of the ministry according to the principle of proportion and proportion between the numbers of trainers and trainees in formations, and this process that The central leaderships at the Ministry's headquarters should take them into consideration, take them into account, and work on them to reduce the gap in this dimension.

\section{CONCLUSION}

Through field visits conducted by the researcher in a number of formations of The Ministry of Interior, it was found that there is a clear interest on the part of the formations in working to develop training processes in them. In addition, there is a clear direction for The Ministry of Interior to work on implementing quality standards in the administrative field, including (ISO 10015: 2019) and (ISO 9001: 2015). In order to provide the best services to the beneficiaries, however, they lack sufficient knowledge of the requirements for implementing these specifications and their need to train and educate workers. Although there is a not small gap between the dimensions specified in the study and the actual reality in the Ministry of Interior, there is a discrepancy in the application of these dimensions, and this confirms that there is knowledge in some aspects, including the dimension of safety and risk management. However, at the same time, we find that most of the formations lack the availability of a system to ensure the quality of services provided by the formations. As well as the weakness of the training activities provided by the ministry to the workers in the formations. Therefore, the study recommends the necessity of paying attention to the application of international standards that help improve administrative activities, including what the current study addressed, which is the guiding specification (ISO 10015: 2019). As the ministry should pay attention to the management of training operations in the ministry because of its importance in enhancing the performance of its employees, which in turn will reflect this performance at the level of services provided by the ministry, as well as the need to strengthen the dimensions that have obtained a higher level of application and attention to and improvement in order to maintain application levels. As well as addressing the high gaps that were identified in some dimensions to reach the desired results from the training processes in the Ministry of Interior. 
International Journal of Business Management and Economic Review

Vol. 4, No. 04; 2021

ISSN: 2581-4664

\section{REFERENCES}

Chang, Y. H., Ling, D. X., \& Quan, X. G. (2004). Literature Review on the Studies of Training Management Conditions in Chinese Enterprises [J]. Scientific Management Research, 1.

Clark, R.E. (1992), "New Techniques for Effective Training Management", Journal of European Industrial Training, Vol. 16 No. 6.

Degraft-Otoo, E. (2012). The effect of training and development on employee performance at Accra polytechnic (Doctoral dissertation, Kwame Nkrumah University of Science and Technology).

Engetou, E. (2017). The impact of training and development on organizational performance. Case study: national finance credit bank Kumba. (master's thesis, Centria University of Applied Sciences).

ISO, international Organization for standardization, ISO 10015:2019 Quality Management guidelines for competence Management and people development, Switzerland, Geneva.

ISO, international Organization for standardization, ISO 9001:2015 Quality management systems - Requirements, Switzerland, Geneva.

Jeni, F. A., \& Al-Amin, M. (2021). The Impact of Training and Development on Employee Performance and Productivity: An Empirical Study on Private Bank of Noakhali Region in Bangladesh. South Asian Journal of Social Studies and Economics, 1-18.

Lin, W. T., Wu, Y. C., Tung, C. L., Huang, M. R., \& Qin, R. S. (2010). Establishing ISO 10015 accreditation system performance model for domestic enterprises. Expert Systems with Applications, 37(6), 4119-4127.

Marnisah, L., Zamzam, F., Handayani, S., Yustini, T., Wijaya, H., Maris, H., \& Irwanto, D. (2021). Factors affecting e-procurement division employee performance. International Journal of Data and Network Science, 5(1), 19-24.

Misra, P. K., \& Mohanty, J. (2021, February). A review on training and leadership development: its effectiveness for enhancing employee performance in Indian construction industry. In IOP Conference Series: Materials Science and Engineering (Vol. 1045, No. 1,

p. 012020). IOP Publishing.

Mwesigwa, A. (2010). The impact of training on employee work performance behaviour. A case study of government aided secondary schools in Ibanda district, (master's thesis, International Institute of Social Studies).

Prasetyo, S., \& Arafat, Y. (2021). The Contribution of Work Motivation and Training Towards Employee Performance at the Inland Water and Ferries Transport Polytechnic of Palembang. KnE Social Sciences, 573-582.

Rahmi, R., Usman, N., \& Murniati, A. R. (2021, February). Education and Training Management in Increasing Teacher Performance. In 4th International Conference on Research of Educational Administration and Management (ICREAM 2020) (pp. 56-59). Atlantis Press.

Seyoum, R. (2015). The Impact Of Training On Employee Performance In Commercial Bank Of Ethiopia Adama District (Doctoral dissertation, Addis Ababa University).

Utomo, J. T., \& Ruslan, S. (2021). THE MANAGEMENT OF A TRAINING DEVELOPMENT STRATEGIES TO INCREASE THE COMPETITIVE ADVANTAGE

OF LIFE LOCAL INSURANCE COMPANIES. Dinasti International Journal of Management Science, 2(4), 639-655. 